\title{
Perception, practice and proximity. Qualifying threats as psychological torture in international law
}

\author{
Ergün Cakal 1
}

\section{Key points of interest}

- International law prohibits threats made by state officials when amounting to torture or ill-treatment.

- What remains problematic, however, is how they are qualified as torture or ill-treatment in criminal justice and other processes.

- Appraising the victim's perception of practice and proximity of state authorities to harm helps qualify threats as "real, credible and immediate".

\section{Abstract}

Background: International law prohibits threats made by state officials when amounting to torture or other forms of ill-treatment (hereafter "ill-treatment"). Yet, there remains a pressing need to better distinguish in practice the threatening acts which amount to torture or illtreatment (and as prohibited) from acts which fall short. Responding to this need, this article reviews the literature and offers a discussion towards functionally conceptualising and, in turn, qualifying threats as torture or ill-treatment.

1) Legal Advisor, DIGNITY - Danish Institute Against Torture, Copenhagen

Correspondence to: erca@dignity.dk
Method: Following a systematic full-text search of databases with the relevant Englishlanguage keywords, journal articles, NGO reports, case-law and UN documents were selected based on their relevance for conceptual, evidentiary and legal critique of threatsas-torture.

Discussion: Prevailing legal reasoning around threats-as-torture centres on the words "real, credible and immediate", with inadequate explication as to their application. To this end, this article proposes that an assessment of the perception of practice and proximity of state authorities to harm could be used to help qualify threats as "real, credible and immediate" and therefore torturous.

Keywords: fear, threats, coercive interrogation, duress, psychological torture.

\section{Rationale and purpose}

The prevalence of threats has been documented in a number of jurisdictions including, to name but two, Turkey and Israel-Palestine (see TIHV, 2019, p. 45; PCATI, 2019: 61\% survivors reported use of threats). In some studies with torture survivors, credible and immediate threats have been considered a distinctly harmful method of torture, especially when they involved threats to relatives (see e.g. Argituz et al, 2014). Threats have been associated with severe mental suffering, 
psychiatric sequel (see Baldwin et al, 2014; Başoğlu, 2009; Reyes, 2008), and chronic pain and other somatic symptoms (see Olsen et al, 2006; Punamäki et al, 2010). In an oftcited study, Başoğlu et al found that the " $[\mathrm{f}]$ ear of threat to safety and loss of control over life appeared to be the most important mediating factors in PTSD and depression" (2005, p. 580).

Notwithstanding this, there exists a considerable degree of ambiguity with respect to the harm (also referred to as "mental anguish" in shorthand) required to bring a threatening act within the ambit of the prohibition against torture or ill-treatment, beyond the fear and stress inherent in and therefore seemingly acceptable to criminal justice practice (e.g. policing and imprisonment). That is to say that threats are often difficult to legally assess and qualify, being disguised under standard operating procedures as legitimate use of force. States have been reluctant to prohibit what they characterise and minimise as mere "certain verbal and non-physical techniques" (House of Commons) or "non-violent psychological pressure through a vigorous and extensive interrogation" (Landau Commission). Courts are also known to legitimise such practices as they are "typically very protective of the police and the integrity of the establishment" (Gudjonsson, 2003, p. 617). This is particularly seen, as the Council of Europe's Committee for the Prevention of Torture (CPT) has noted, in any "criminal justice system which places a premium on confession evidence [as it] creates incentives ... to use physical and psychological coercion" (2002, \$35). The need for clarification and explication, therefore, is patently pressing.

The salience of this pursuit is amplified in light of contemporary struggles particularly against coercive interrogation that have the propensity to amount to torture and ill- treatment. Indeed, in making a convincing case for a protocol on non-coercive interviewing, the UN Special Rapporteur on Torture (UNSRT) at the time Juan Mendez pointed out that, depending on their "degree, severity, chronicity and type, undue psychological pressure and manipulative practices" may amount to ill-treatment (2016, \$44). The ensuing effort has been to formulate guidelines outlining good interviewing practices but, significantly, not the redlines or functional criteria demarcating the coercive from noncoercive. This is also very much a need the subsequent UNSRT (2020, \$38) identifies in pointing to the "practical importance of continuing to clarify the fault lines between lawful non-coercive investigative techniques and prohibited coercive interrogation". ${ }^{1}$

This article focuses primarily on interrogational contexts, and secondarily draws on cases involving non-custodial settings. Whilst threats aimed at extracting confessions and information remain the focus, threats for other purposes such as intimidation, punishment and discrimination are also discussed where relevant. My aim is twofold: to outline the current jurisprudence on threats via a literature review and to elaborate and explicate a new conceptual approach to help qualify threats, particularly those which are subtle and tacit, as torture or ill-treatment. This article takes a first step in identifying the factors relevant to considering such covert threats as torture.

Part II locates existing literature which define and categorise threats - illustrating and invoking acts considered relevant to the discussion. Part III enumerates the normative

1 Needless to say, this has been a long-standing issue (see also UNSRT, 2001, \$7, urging states to raise judicial awareness on threats). 
prescriptions which squarely and specifically prohibit threats which amount to torture or ill-treatment under international law, before offering a review of the relevant case-law. Part IV details concepts upon which legal assessments and qualifications are - or should be - made. Part V problematises the judicial reasoning and formulations in the uses of "real", "credible" and "immediate", articulating them through the three notions of perception, practice and proximity.

\section{Definition and categorisation}

The idea of anticipated harm propelled for a coercive end is at the centre of the definition of "threat": e.g. "a threat of harm made to compel a person to do something against his or her will or judgement" (Black's Law Dictionary, p. 542, 8th Edition, 2004) or "declaration of an intention to punish or hurt ... a menace of bodily hurt or injury, such as may restrain a person's freedom of action" (OED, 1990). In the absence of coherent and universal distinctions between the notions of "threat", "fear", "coercion", "intimidation", “distress", “duress" and "anguish", this article treats them as near-synonymous as does the surveyed literature, except where specified.

There is no universally accepted legal definition of a threat or an authoritative list of what constitutes a fear-inducing method which violate the prohibition of torture and ill-treatment. A survey of the jurisprudence reveals that threats are "neither definitively nor consistently defined" (Guiora, 2008b, p. 88). Guiora ventures one definition of threats as entailing "interrogation methods inducing a suspect to provide his interrogator(s) with information when under the impression that to do otherwise will result in penalty either to himself or to others" (2008a, p. 414). Argituz et al propose another definition as the "advance notice of harm that is going to be brought about if the detainee's actions do not go in the direction desired by the questioner" (2014, p. 77).

The category of "fear-producing actions" in Pérez-Sales' Torturing Environment Scale is instructive in illustrating the types of acts at issue here, as follows: a. hopes and expectations; b. threats to the person (e.g. endless isolation, endless interrogation, rape, pain, torture, death); c. threats against family or relatives (next-of-kin) (e.g. rape, detention, punishment, retaliation), or threats against other detainees); d. anguish associated with lack of information (e.g. relatives of people detained/ disappeared); e. experiences of near death (e.g. mock executions, dry/wet asphyxia); f. witnessing others' torture or death; g. use of situations evoking insurmountable fear (e.g. phobias, total darkness); h. other situations provoking fear or terror (2017, p. 360). Moreover, Ojeda also formulates a similar categorisation as: threats to self or to other; threats of death, physical torture or rendition; mock executions; forced witnessing of torture (visually or aurally) (2008, p. 3).

There is significant overlap in references to notions of threatening and fear-inducing methods. For instance, the Istanbul Protocol recognises threats, in its multitude of derivations, as a method of torture including: i. "threats of death, harm to family, further torture, imprisonment, mock executions"; and, ii. "threats of attack by animals, such as dogs, cats, rats or scorpions" (OHCHR, 1999, \$145 o-p). Recognised visually-oriented threats extend to displaying torture equipment and dangerous objects or animals (see Reyes, 2007, pp. 604-605) and the mere presence of "wooden sticks, broom handles, baseball bats, metal rods" etc. (CPT, 2002, \$39; see also ACHPR, Elgak and Ors v. Sudan; ECCC, Duch, Case No. 001, §245). 


\section{Legal anchoring: a review of prohibitions and case-law}

This section canvasses and draws upon sources of law with varying degrees of authority and scope. I merely seek to reproduce salient points in the law and literature, without detailed comment as to weight or priority.

\section{Prohibitions}

Despite the definitional ambiguities, coercive and threatening acts by officials are widely recognised to invoke the prohibition of torture and ill-treatment. Remaining alert to the "problems posed in respect of securing evidence of non-physical forms of torture", the UNSRT mandate has consistently held that "fear of physical torture may itself constitute mental torture" as: "serious and credible threats, including death threats, to the physical integrity of the victim or a third person ... especially when the victim remains in the hands of law enforcement officials" (UNSRT, 2001, $\$ \$ 7-8$ and 3; see also UNSRT, 1986, \$119; UNSRT, 1998, \$208). The UN Committee Against Torture (CAT) has also consistently found threats as amounting torture and ill-treatment (2008a, $\$ 7 ; 2006, \$ 24 ; 2003$, IS143-144).

Furthermore, Principle 21 of the UN Body of Principles for the Protection of All Persons under Any Form of Detention or Imprisonment (UNGA, 1988) prohibits (1) taking "undue advantage of the situation of a detained or imprisoned person for the purpose of compelling him to confess, to incriminate himself otherwise or to testify against any other person", and (2), "threats or methods of interrogation which impair his capacity of decision or his judgement" during interrogation.

Similar prohibitions also emanate from international criminal law and international humanitarian law. Notably, article 55 of the Rome Statute of the International Criminal Court pro- hibits "any form of coercion, duress or threat" during investigations. Moreover, Geneva Conventions, at several points, prohibit prisoners of wars from being subjected to threats, coercion or insults during and outside of interrogations. Article 17 of the Third Geneva Convention, for instance, states that: “[p] risoners of war who refuse to answer may not be threatened, insulted, or exposed to unpleasant or disadvantageous treatment of any kind." Article 4 of the Protocol Additional to the Geneva Conventions prohibits "(a) violence to the life, health and physical or mental well-being of persons, in particular murder as well as cruel treatment such as torture, mutilation or any form of corporal punishment ... (and) (h) threats to commit any of the foregoing acts." Furthermore, ICRC Commentary to the Additional Protocols provide that " $[\mathrm{i}] \mathrm{n}$ practice threats may in themselves constitute a formidable means of pressure and undercut the other prohibitions. The use of threats will generally constitute violence to mental well-being within the meaning of subparagraph (a)" (ICRC, 1987, \$4543. p. 1376).

In sum, the prohibition of threats under international law amounting to torture and ill-treatment is clear.

\section{Case-law}

This clarity quickly dissipates upon even a cursory reading of the case-law. There is a gap between these prohibitions and case law, which the existing scholarship doesn't address. Taking it as a given, I do not seek to explain the existence of this gap. Instead, what I will try to do is to explicate an approach in applying the prohibitions on threats. There are some examples of threats such as mock executions which would more clearly fall afoul of the prohibitions. In most other instances, particularly with less overt threats, we are compelled to more carefully appraise 
impact and gravity. Taking stock of the complexities posed by interrogational stressors, the element of severity remains central and problematically significant. What will be seen is that the law equates severity of harm with the appraisal of threats, subjectively and objectively.

I have also chosen not to dwell on distinguishing between threats as torture from ill-treatment - as both are prohibited. It suffices to say that, as with Mendez and Nicolescu (2017, p. 244), I presume that intentionality is broader than solely the deliberate as it can also be satisfied by recklessness (though not negligence). The case-law cited below posits that intentionally or recklessly deploying fear to create a threatening situation against the individual, either directly (explicit threats) or indirectly ("atmosphere of terror"), falls afoul of the prohibition of torture. This may not be so readily presumed in non-interrogational and non-custodial settings - where the purpose and intent may not be as patent.

Due to its relatively extensive life-span and case-law, I will primarily consider cases from European jurisprudence which are conducive for both mentioned purposes (i.e. outlining the jurisprudence and indicating a conceptual framework). To start chronologically, the Greek Case is arguably the first international case which identified non-physical torture to include: "mock executions and threats of death, various humiliating acts and threats of reprisals against a detainee's family" (ECommHR, \$186). The European Court of Human Rights (hereafter "the European Court") further articulated its position on threats in Campbell and Cosans v. United Kingdom where it found that "provided it is sufficiently real and immediate, a mere threat of conduct prohibited by Article 3 may itself be in conflict with that provision. Thus, it established the rule that to threaten an individual with torture might in some circumstances constitute at least 'inhuman treatment"' $(\$ 26$, as followed in El Masriv Macedonia (where applicant was threatened with a gun), \$S 202-204; Husayn (Zubaydah) v Poland, $\$ 501$ (where the applicant was threatened with ill-treatment)).

Gäfgen v. Germany somewhat advanced the discussion. There, the European Court rendered torture "the real and immediate threats of deliberate and imminent ill-treatment ... [as having caused] considerable fear, anguish and mental suffering" ( $\$ 103)$, and considered it noteworthy that the threat "was not a spontaneous act but was premeditated and calculated in a deliberate and intentional manner" $(\$ 104)$. Furthermore, the state of "particular vulnerability and constraint" (the applicant was handcuffed in the interrogation room) and the "atmosphere of heightened tension and emotions" (the police were under pressure to locate the whereabouts of a kidnapped child) ( $(106)$ in which the threat took place was also an explicit factor in the Court's assessment (see $\$ \$ 80-81$ ). The Court ultimately prescribed that whether any threat of physical torture amounted to psychological ill-treatment depended on the individual circumstances of a case primarily "the severity of the pressure exerted and the intensity of the mental suffering caused" ( $(108)$.

The requirement of real danger also emerges as a central criterion when surveying Inter-American jurisprudence, where "real danger of physical harm" is held to amount to psychological torture (Baldeón-García v. Peru, $\$ 119$, citing Maritza Urrutia; Cantoral-Benavides). In Tibi v. Ecuador, for instance, the Inter-American Court recognized that "threats and the real danger of subjecting a person to physical injury, under certain circumstances, cause such a moral anguish that they may be considered psychological torture” $(\$ 147)$. 
Several points discerned from the review can be readily summed up without necessitating elaboration. Firstly, there has been no explicit judicial reasoning speaking to any qualitative hierarchy between the verbal and non-verbal, the explicit and implicit. Secondly, the following categories (inexhaustive, overlapping) of threats have been found to violate the prohibition of torture and ill-treatment: threats to life (including non-verbal threats such as display of torture implements and mock executions); threats to inflict violence; threats to family members; and, witnessing the tortured, the executed and the enforced disappeared. Additional cases will be relied upon in the following sections.

These cited cases involve explicitly serious threats to a person. Critically missing in the jurisprudence is what and how threats falls short of "sufficiently real and immediate". The question thus becomes how we should interpret the qualifying criteria we are collecting in the foregoing jurisprudence ("real", "severe", "immediate", "credible", "premeditated", "imminent”, "particular vulnerability", "constraint"). A functional appraisal is appropriate here. For severity, we must naturally turn to the psychological impact of threats; for immediacy, we may well ask: "how imminent?" There is also a seemingly objective question about measuring credibility - that there are substantiated grounds that the communicated threat will be acted upon, e.g. previous or personal (witnessing) knowledge of the perpetrator's ill-treatment or impropriety. In sum, judicial reasonings become underpinned by a language of risk appraisal.

What is essentially called for is an appreciation of state power through the eyes of the individual, by assessing the likelihood that a threat would be acted upon. Although a question with clearly different legal parameters, the UN Committee Against Torture has adopted a similar approach in guiding their assessments under article 3 (non-refoulement) of whether the risk of torture upon deportation - in a third country - is "foreseeable, personal, present and real" (CAT, 2017b, \$11). The language of risk appraisal will be returned to in Part V.

\section{Contextual considerations: legality, vulnerability and totality}

As with all psychological methods of torture, threats are difficult to identify due to overarching conceptual and evidentiary complexities (see Cakal, 2018; 2019) due to not leaving physical marks, being trivialised by state authorities, and being combined with other methods (see, e.g., CAT, Martinez v. Mexico; CAT, S.S.B v. Denmark). Here, the considerations of legality, vulnerability and totality are employed to assist in contextually situating the use of threats, explicating and contesting what is obfuscated as "standard operating procedure" and underappreciated as "mild" force.

\section{Legality}

The spectrum of harm is broader than the gruesome instances illustrated by the caselaw - which are arguably easier to assess as unjustified uses of state power - whereas those conceived to be tacit, mundane and everyday become difficult to assess and qualify as being harmful. To put this another way, while uses of minimal discomfort have been argued as remaining legitimate (as law enforcement institutions inevitably instil some degree of fear and anxiety), accusatorial, protracted or suggestive interviews overlaid with implicit or explicit threats are problematic. Discussed at length elsewhere (Pérez-Sales, 2017, p. 328), the contestation between discomfort and pain, worry and fear become central here.

It should be accepted that the state takes an "inherently threatening position" against 
the individual (Guiora, 2008b, pp. 88-89). This necessitates a certain determination of the "baseline" or "inherent inequality" of the interrogation process and, in turn, "whether an interrogator's actions increased this inherently threatening situation to impose undue force on the individual to confess" (Guiora, 2008a, p. 414).

Advancing a more categorical argument, Ginbar observes that "international law does not recognize 'coercive interrogation' that is lawful or justifiable" (p. 277). He couples the prohibition against "physical or moral coercion ... in particular to obtain information" as found in Geneva Convention IV (\$\$ 5, 27, 32, 37) with UN Body of Principles' edict to interpret ill-treatment in a manner to "extend the widest possible protection" to argue that any form of coercion amounts to ill-treatment (p. 277).

Yet, not all fear arising out of criminal justice practice is legally unjustified, particularly that which is implicit in custodial and interrogational settings. The level of fear acceptably "inherent" becomes a central question here. This discussion also invokes the requirement, a creation of the European Court, that any allegation of torture or ill-treatment first satisfy a minimum level of severity to violate the prohibition against torture or ill-treatment. The Court has interpreted this in various ways as an experience other than "difficult" or "undoubtedly unpleasant or even irksome" (Guzzardi v. Italy, §107).

Also apposite here is the progressive principle from Selmouni v. France which "considers that certain acts which were classified in the past as 'inhuman and degrading treatment' as opposed to 'torture' could be classified differently in future" corresponding to prevailing, increasing social standards with respect to human rights protection ( $\$ 101)$. This may well see certain acts falling short of the minimum level today prohibited over time. Ultimately, ostensibly objective assessments must be strictly checked against the subjective, erring on the side of the latter, even if we are to risk "meaningless" saturation (see, e.g. dissenting opinion in Bouyid v. Belgium).

It is important to bear in mind that this article overlooks, due to space, the distinction between acts are prohibited as amounting to impropriety or non-compliance with procedural rules and acts prohibited as amounting to torture and ill-treatment - except perhaps to point out that impropriety could be an indicator that harm is also present. The absence of essential safeguards in custody, particularly the access to a lawyer, health professional and the right to notify a third party, are important in this assessment. Conversely, the UNSRT has also stated that there is no simple oneto-one equation here, arguing that the length, prolonged delay or indefiniteness of detention, albeit central and harmful, does not alone amount to ill-treatment (UNSRT, 2012, \$47). I return to this point below in the discussion on proximity and powerlessness.

\section{Vulnerability}

Vulnerability may be approached in two different ways: situational and dispositional. The situational approach "draws attention to the situation of people who find themselves at elevated fragility or 'risk of harm' due to biological circumstances, situational difficulties or transgression" (Brown 2015, pp. 28-31). The dispositional accounts advance that all individuals are inherently vulnerable - as we are all dependent thus could be put under duress by criminal justice practice - thereby shifting the focus from the individual to systemic characteristics. It may also be that an individual's perception may be more severe than what we attribute to it from a position of "reasonableness" or "objectivity". 
An indispensable point to factor in is that no one reacts identically to identical treatment. A prominent dimension of psychological torture is mapping psychological vulnerabilities of a human being in personalizing the treatment or punishment. One way is the use of elements of personal identity (e.g. gender, age, culture, religion) against the person; another is the use of cultural and religious elements to produce mental suffering. Certain acts in and of themselves may be viewed as harmless when divorced from the symbolism, connotations and meaning attributed by the victim (e.g. the taboo of nakedness, forceful breaking of religious obligations or rules linked to dressing, food or practices).

The legal assessment of the minimum level of severity - not just limited to psychological torture - also "depends on all the circumstances of the case, such as the duration of the treatment, its physical or mental effects and, in some cases, the sex, age and state of health of the victim" and that context must be taken into account, including an "atmosphere of heightened tension and emotions," also drawing in context and totality of conditions and treatment (Bouyid $v$ Belgium, §86). ${ }^{2}$ Leaning on such a more embodied and embedded approach to vulnerability would help correct the underestimation of the impact inherently stressful environments inflict on particular individuals (Dehaghani, 2020). I will return to this in the discussion on perception.

2 Soering v. the United Kingdom is a similar point of reference here where the Court had particular regard to documented conditions of death row, the personal circumstances of the applicant, especially his age and mental state at the time of the offence $(\$ 111)$.

\section{Totality}

The analysis of torture methods should not obscure the fact that in many cases it is not a question of the application of isolated methods of torture, but of the combination or sequential accumulation of methods. It must also be born in mind that there is a fluid continuum between torturous acts and methods and conditions and context. That is to say that it is difficult to distinguish between the stressors part of the background environment and actions that are readily identifiable in the foreground as distinct torture techniques. Coercion is profoundly difficult to accurately measure as it depends on a matrix of factors, physical, cultural, linguistic and individual. Pérez-Sales holds that the "presence or absence of torture is defined not by technique, but by the context and the way in which techniques are applied" (2017b, p. 8). His Torturing Environment Scale emphasises both the specific and cumulative nature of detention conditions to counter this problem (Pérez-Sales, 2017).

There also seem to be relatively numerous documented cases of ill-treatment where threats are singularly considered, making it seem relatively easier to isolate them, at least jurisprudentially (see, e.g., ECHR, Gäfgen v. Germany). This is an illusion, however; context is inescapable. That is to say, whilst threats are said to be torturous on their own as a rule of thumb, it is clear from cases following Gäfgen that contextual factors predominate in judicial assessments of torture or ill-treatment. Cases following Gäfgen have not expanded upon threats though some have emphasised the importance of contextual factors (e.g. an "atmosphere of heightened tension and emotions”, Bouyid v. Belgium, $\$ 86$; Al-Masri, for instance, did not elaborate at all).

There have been similar rulings seemingly indicating the sufficiency of certain threats on their own (Prosecutor v. Brdanin, 2004, \$516: 
where the threat of rape on its own constituted an assault; Prosecutor v. Simić, 2003, \723: where an unloaded gun was pressed to the heads of interrogees and pulled, the "psychological burden on the detainees was immense"). The preponderance of the International Criminal Tribunal for the former Yugoslavia (ICTY) jurisprudence, however, has also relied on a notion of "atmosphere of terror", which in Delalic denoted a fear in all persons subjected to a regime. There, the ICTY ruled:

It is clear that, by their exposure to these conditions, the detainees were compelled to live with the ever-present fear of being killed or subjected to physical abuse. This psychological terror was compounded by the fact that many of the detainees were selected for mistreatment in an apparently arbitrary manner, thereby creating an atmosphere of constant uncertainty. ( $(1087)$

Conversely, in one report, the UNSRT observes that the "mere fact of detention had the same implication" as the threat of torture $(2001, \$ 7)$. This may, at first glance appear to be a potentially controversial claim that does not find immediate substantiation in international law. As put earlier, not all fear arising out of detention gives rise to an unacceptable level of harm. Yet, when we frame it contextually (here perhaps drawing on the absence of crucial safeguards and due process), the appraisal would become substantiated and grounded.

Similarly, a focus on the accumulation of certain psychological stressors (both context and methods) is merited in better understanding and assessing the environmental harms at play informing the appraisal of a threat. That is, manipulation and compounding stressors in terms of environmental conditions and treat- ment must also be borne in mind. Solitary confinement and denial of visits, for instance, can be used as non-verbal "softening" methods when coupled with coercive interviewing including threats. The potentially powerful influence of the physical regime of confinement is irrefutable as it "supports and facilitates these pressures and the effect becomes more pronounced the longer the total period of detention in police custody" (Hilgendorf \& Irving, 1981, p. 81 ). The surrounding circumstances of the arrest and custody (such as how sudden and violent the arrest was) and the timing of the interrogation (i.e. day or night) are likely to be instructive here to understand the mental and physical state of the victim (Gudjonsson, 2003, p. 311-12).

Başoğlu also notes this problem concerning the inclination to treat specific systemic conditions, albeit harmful, as background factors "rather than as an independent force or factor that exacerbates the harm, or as a form of torturous treatment itself" (2018, p. 140). He further finds that increasing awareness of the pains and long-term harms of imprisonment:

may well mean that the calculus applied to certain forms of previously unquestioned "lawful" confinement must be modified and made more stringent. Among other things, this knowledge makes it much easier to demonstrate that certain prison procedures and practices were, in fact, "calculated to disrupt profoundly the senses or personality," given what correctional officials and prison staff knew or should have known about the harmfulness of such conditions and treatment. (2018, p. 144)

The UNSRT (2020 $\$ 47(a))$ has also recently outlined a useful taxonomy to under- 
stand the environment in which psychological stressors (including fear-inducing mechanisms such as direct or indirect threats) are conveyed and amplified - and the common aspects of stress and coercion which affect how a particular situation is experienced and perceived. $\mathrm{He}$ identifies the following aspects in this respect: security (inducing fear, phobia and anxiety); self-determination (domination and subjugation); dignity and identity (humiliation, breach of privacy and sexual integrity); environmental orientation (sensory manipulation); social and emotional rapport (isolation, exclusion and betrayal); and, communal trust (institutional arbitrariness and persecution). These may be instructive in the complex challenge presented by appraisals of fear and threat.

To also more comprehensively capture the context in which torture is inflicted, the European Court has developed extensive jurisprudence on psychological suffering inflicted directly or as exacerbated by subjecting individuals to "permanent states of anxiety" (Azzolina et Autres c. Italie, \$133) including in specific contexts such as incommunicado detention (Aydin v. Turkey, \$84), extraordinary rendition and secret detention (Husayn ( $\mathrm{Abu}$ Zubaydah) v. Poland, \$\$509-510), ill-treatment outside a formal place of detention and mass arrests accompanied by gratuitous violence (Azzolina et Autres c. Italie, \$\$133-134). The jurisprudence of the CAT, the Human Rights Committee and the Inter-American Court is also replete with similar findings speaking predominantly to "anguish and distress" or "great suffering and anguish". ${ }^{3}$

3 See, e.g., Bousroual v. Algeria, CCPR/ C/86/D/1085/2002, \$§9.8, 10; Giri v. Nepal, CCPR/C/101/D/1761/2008, \$7.7; Kimouche v. Algeria, CCPR/C/90/D/1328/2004, \$7.7; Quinterrros v. Uruguay, CCPR/C/19/D/107/1981, \14; Larez v. Venezuela, CAT/C/54/D/456/2011,

\section{Conceptual contours: towards qualification}

The legal review in Part III implicated a number of factors at play in qualifying a threat as causing sufficient mental anguish to rise to the level of torture or ill-treatment: the content of the threat; the context in which it was communicated (upon the totality of the victim's experiences); how it was perceived (believed/apprehended/appraised); how the victim's perception is checked, corroborated and qualified. Putting these factors together suggests a key question: did the victim perceive/believe that the state authorities were able, prone and close to act upon the threats made? This assessment would incorporate both an objective and a subjective aspect: that is, how it was perceived by the victim (subjective) upon the backdrop of conditions and treatment, and broader context (objective).

These inform the belief of the likelihood that threats would be carried out, the consequences of the threat and the emotional response of those subjected. The three lenses of perception, practice and proximity admittedly overlap and cannot be strictly delineated. They are offered as broad heuristic groupings covering a range of factors. Bearing this in mind, the following discussion will aim to locate their core, through selective illustrations from the case-law. I should repeat here that my concern is more in addressing instances of covert or more ambiguous threats rather than overt threats, say mock executions, that much more readily rise to the level of torture. Thus the

§6.10; Ali v. Tunisia, CAT/C/41/D/291/2006, \$2.5; González v. Mexico, Preliminary Objection, Merits, Reparations, and Costs, Judgment, Inter-Am. Ct. H.R. (ser. C) No. 205, $\$ \$ 424-440$; Álvarez v. Guatemala, Merits, Reparations, and Costs, Judgment, Inter-Am. Ct. H.R. (ser. C) No. 253, \$301. 
focus becomes an exercise in explicating the gravity of the more tacit instances of threats.

\section{Perception: subjective appraisal}

Perception, or subjective appraisal, is advanced here as the subjective measure of severity of harm (namely, mental anguish). It centres on the individual appraisal of the likelihood of the threatened act being carried out as well as the gravity of the suffering experienced. The following aims to partly map out the considerations with respect to what informs and warps perception.

Naturally, the meaning a victim brings to a stressor is significant, as the appraisal of threat "occurs at the information-processing level of analysis embodied in the brain ... [and as such] being threatened with a handgun can on be psychologically traumatizing if one knows what a gun is" (Başoğlu, 2018, p. 190). Individual vulnerabilities may influence the perception as may the conditions. Coercion therefore not only stems from "external stimuli but also from self-induced pressures, which results from an individual's interpretation of and chosen response to events, both real and imagined" (Dimitriu, 2013, p. 549).

Accepting some variance, Başoğlu (2018) concludes that fear in the face of threats to safety is in fact universal cutting across cultures and species, (p. 34) and that "threat appraisal can override many other factors that mitigate the effects of trauma, including resilience" (p. 28). Outlining the related stresses involved in interrogation, Pérez-Sales also states that that the individual in interrogation usually:

feels high levels of anxiety and fear because of the conditions of detention (even if they are not harsh conditions), isolation (including being alone with one's thoughts), lack of control and uncertainty about what will happen next, how long the situation will last and the potential consequences. This can clearly impair the subject's ability to remember, to think clearly and logically, and to make proper decisions. Thus, the experience of interrogation is not a neutral encounter between two people, even under normal conditions. (2017b)

An individual's perception may indeed be sufficient to deem a threat to violate the prohibition of torture or ill-treatment. Such a conclusion - at least in terms of degrading treatment - was drawn by the Grand Chamber of the European Court in Bouyid v. Belgium where it held that: "it may well suffice that the victim is humiliated in his own eyes, even if not in the eyes of others" (\$87). The characteristics of the victim are as always at play here including, to name but a few, age and gender (Shaked-Schroer et al, 2015, p. 78), social status (see Davis \& O'Donohue, 2004), ethnicity, health, lack of life experience, unfamiliarity with police procedures and failure to understand legal rights, and "cognitive skills (e.g. intelligence, reading ability, attentional deficits, memory capacity), personality (e.g. suggestibility, compliance, assertiveness, selfesteem, tendency to confabulate, anxiety proneness), specific anxiety problems (e.g. claustrophobia, fear of being isolated from significant others, extreme fear of police dogs), mental illness (e.g. depressive illness, psychosis) and personality disorder" (Gudjonsson, 2003, pp. 311-312).

Ultimately, it is argued that, as with many legal qualifications of belief, this remains open to being weighed against and corroborated by more contextual factors, such as established practice and proximity - to which the discussion will now turn. 
Practice: knowledge and experience of patterns and predisposition

The concept of practice here is defined as a pattern, contextually-informed and objectively verifiable, showing that the authorities are prone or predisposed to act on threats. It need not necessarily be profoundly historic or systemic as it may be specific to a period of time such as a highly politicised or pressured event (e.g. elections) or the aftermath of a violent attack (or in the case of Gäfgen a kidnapping where time was of the essence), geographical location such as a certain notorious police station, or towards a member of a particular social group such as ethnic minorities, human rights defenders etc.

There are numerous cases in which the use of methods other than threats inform the victim's appraisal of the threat. On the backdrop of a "pervasive climate of fear", in Elgak and Ors v. Sudan, the African Commission found a violation of torture and ill-treatment (not specified) based on a mixture of credible threats, threats of rape, cigarette burns, and the display of torture instruments. The victims there, who were human rights activists, argued that the "pervasive nature of the threats was both real and serious and the circumstances in which they found themselves were so serious that they caused them severe mental pain and suffering" (\$76). Beyond underscoring the importance of totality of treatment, this case exemplifies the importance to the assessment of credibility on the materialisation of threats by way of the infliction of physical pain.

Known or uncertain fate of third-parties, related or with a similar profile, is also rendered significant in the jurisprudence. In Estrella v. Uruguay, the UN Human Rights Committee found that the victim was "subjected to severe physical and psychological torture, including the threat that the author's hands would be cut off by an electric saw, in an effort to force him to admit subversive activities" (\$8.3). At one point, the victim was threatened with: "we are going to do the same to you as Victor Jara". Relatedly, in Mukong v. Cameroon, the Human Rights Committee found a violation of article 7 of the International Covenant on Civil and Political Rights (cruel, inhuman and degrading treatment), where the victim had taken threats of death "seriously, as two of his opposition colleagues, who were detained with him, had in fact been tortured" ( $\$ 2.5)$. Moreover, finding torture in Maritza Urrutia v. Guatemala, the Inter-American Court established that, amongst other methods such as hooding and sensory bombardment, the victim was "shown photographs of individuals who showed signs of torture or had been killed in combat and [...] was threatened that she would be found by her family in the same way. The State agents also threatened to torture her physically or to kill her or members of her family if she did not collaborate" (\$85).

The fact that threats follow other violations are also instructive here. Illustrating this, in the Case of the "Street Children" (Villagran-Morales et al.) v. Guatemala, the Inter-American Court held that a person "unlawfully detained is in an exacerbated situation of vulnerability creating a real risk that his other rights, such as the right to humane treatment and to be treated with dignity will be violated" $(\$ 166)$. Conflating the verbal and the non-verbal, the case also expounded the stance that "creating a threatening situation or threatening an individual with torture may, at least in some circumstances, constitute inhuman treatment" $(\$ 165)$. The Court also required threats as needing to be "sufficiently real and imminent" - going on to rule that, for the reasons outlined, they were.

In Prosecutor v. Krnojelac, the ICTY concluded that it was inhuman and degrading 
treatment for detainees to be subjected to a torture regime with individuals being randomly selected for beatings which all others heard $(\$ 56)$ creating a "climate of fear" $(\$ 194$; see also Prosecutor v. Blaskic, \$700; Prosecutor v. Naletilic, \$394; Prosecutor v. Simić, \$\$731, 967). It may be important to note that these cases emanate from the concentration camp, explicitly dehumanising milieu common to violations of international criminal law - and serves to emphasise the context upon which threats are made.

Through these examples, we see that state authorities support the credibility of their threats in producing mental anguish through various means - including display of photos and demonstration of their knowledge, power and predisposition to harm - with impunity as the victim is made to believe that the act is imminent and forthcoming. This is also coupled up with the proximity (or the physical possibility of the authorities to act to achieve the threatened consequences) - to which the discussion will now turn.

\section{Proximity: powerlessness and constraint}

Cases involving police interrogations heard before international courts feature distinct tactics that draw our attention to proximity, powerlessness and constraint. These are readily discerned in a custodial context but perhaps less so in the non-custodial. Subject to the victim's perception, additional aspects are implicated: the physical closeness of state officials essentially to the threatened target of harm be it the victim or their family members; the prospects of impunity; and, strength of legal protections as applied to the specific situation.

The notion of powerlessness has been deployed by commentators to capture such dynamics. Even in the absence of coercion, to quote Gudjonsson, the "interrogator is part of a system that gives him or her certain powers and controls (arrest and detention, power to charge, power to ask questions, control over the suspect's freedom of movement and access to the outside world)" (p. 25). Powerlessness may be compounded as the individual to whom a threat is made is put into a dynamic of responsibility, or perceived "complicity", for another's suffering (see fager v. Netherlands).

A number of cases directly invoke physical proximity. An illustrative case is found in Nechiporuk and Yonkalo v. Ukraine where a couple were taken into police custody. There, the European Court held that the husband's knowledge of his wife's custody, as well as her being in an advanced stage of pregnancy, "must have exacerbated considerably his mental suffering" (\$156). Similarly, in Elci v. Turkey, a husband and wife were brought into interrogation together, before being interrogated separately, the husband was then threatened that his wife would be raped if he failed to confess. This was held to amount to ill-treatment (for a similar case see UN Human Rights Committee in Khalilova v. Tajikistan).

In a non-custodial context, in Musayev and Others v. Russia, the European Court found it to be inhuman and degrading treatment for the victim to have witnessed the "extrajudicial execution of several of his relatives and neighbours [before being] forced at gunpoint to lie on the ground, fearing for his own life" ( $\$ 169)$. Similarly, in the Inter-American Court Case of the Rochela Massacre v. Colombia, three survivors of a massacre who "felt the possibility that they might die in those moments as well [...] knowing that the paramilitaries could return at any moment" (\$135). There, the Court underscored the "intense psychological suffering of the survivors" and the "profound fear that they would be deprived of their lives in a violent and arbitrary manner" arising from the witnessing of torture and execution in finding that it constituted torture $(\$ 136)$. 
Relatedly, the "distress and anguish" engendered by the uncertainty of enforced disappearances coupled with a lack of an adequate response on behalf of the authorities have also drawn the ire of the European Court. El-Masri supports the position that enforced disappearance is a contravention of article 3 as the Court there found that the applicant's solitary confinement in the hotel "must have caused him emotional and psychological distress", that "prolonged confinement ... left him entirely vulnerable" and that he "undeniably lived in a permanent state of anxiety owing to his uncertainty about his fate" $(\$ 202)$. Similarly, the Inter-American Court has ruled that "it is inherent in human nature that all those subjected to arbitrary detention, incommunicado, torture and forced disappearance experienced intense suffering, anguish, terror, and feelings of powerlessness and insecurity" (Goiburu et al v. Paraguay, \$157).

Even in the absence of explicit threats, the power differential between the state and the individual remains to be of contextual importance. The European Court has recognised that "persons who are held in police custody or are even simply taken or summoned to a police station for an identity check or questioning [and] more broadly all persons under the control of the police or a similar authority, are in a situation of vulnerability" (Bouyid, \$107). Similarly, in Magee v. the United Kingdom, (not finding a violation of the prohibition of torture and ill-treatment but right to a fair trial (article 6)), the European Court observed:

The austerity of the conditions of his detention and his exclusion from outside contact were intended to be psychologically coercive and conducive to breaking down any resolve he may have manifested at the beginning of his detention to remain silent. Having regard to these considera- tions, the Court is of the opinion that the applicant, as a matter of procedural fairness, should have been given access to a solicitor at the initial stages of the interrogation as a counterweight to the intimidating atmosphere specifically devised to sap his will and make him confess to his interrogators. (\$43)

Such considerations have also been closely examined in other jurisdictions such as the United States. In Oregon v. Mathiason, for instance, the Oregon Supreme Court broadly recognised that "[a]ny interview of one suspected of crime by a police officer will have coercive aspects to it, simply by virtue of the fact that the police officer is part of the law enforcement system which may ultimately cause the suspect to be charged with crime". The US Supreme Court also followed this reasoning in Miranda v. Arizona where it "concluded that without proper safeguards the process of in-custody interrogation of persons suspected or accused of crime contains inherently compelling pressures which work to undermine the individual's will to resist and to compel him to speak where he would not otherwise do so freely" (\$467). In Dickerson v. United States, the Supreme Court ventured that:

custodial police interrogation, by its very nature, isolates and pressures the individual ... that even without employing brutality, the 'third degree' or other specific stratagems, custodial interrogation exacts a heavy toll on individual liberty and trades on the weakness of individuals. We concluded that the coercion inherent in custodial interrogation blurs the line between voluntary and involuntary statements ... (\$435) 
In sum, proximity, particularly arising out of spatial (i.e. location, physical context) and temporal (i.e. timing, duration) factors, informs an assessment of vulnerability and imminence that a threat can and will be acted upon. In other words, the closer one is to a law enforcement official, whether in custody or in the community, the more heightened one's vulnerability as tempered by the known practice of the state in applying the force legitimately.

\section{Towards qualification}

The following questions may assist in crystallising the assessment and adjudication of threats in practice:

1. What were the series of events and stressors present in the environment in which the threat was made?

This alludes to discussions of contextualisation, totality and accumulation which were made above. These circumstances would also help in inferring purpose and intent, if not already explicit. See Part IV.

2. Does the threatened act amount to torture or ill-treatment?

This is a broader assessment of the content of the threat, or the threatened consequences (i.e. serious harm being inflicted to family member; possibility of sexual violence; humiliation, etc.), and invokes the specific jurisprudence pertaining to the assessment of that act. Excluded here would be legal sanctions compliant with international human rights law, for instance. Reference to legality of the threatened outcome (e.g. a proportionate sentence of imprisonment through due process) may be instructive here. This is about the nature of the outcome, and not how it is made. If the threatened outcome does not amount to torture or ill-treatment, there is no need to proceed. See also legality in Part IV.
3. Did the victim (person to whom the threat was made) perceive/believe that the official (person making the threat) was willing and able to act upon the threat?

This is a subjective assessment of the victim's appraisal of the situation based on their understanding and knowledge of state practice, including as informed by: vulnerabilities, previous experience, membership of a group at particular risk of torture, knowledge of historical patterns, strength of procedural safeguards, materialisation of threats, and prospects for impunity. See discussion on perception and proximity in Part $V$.

4. How likely was it that the threat could or would be acted upon?

This is an objective assessment of the particular risks (also as above historical patterns, facts in similar cases), access to person, strength of procedural safeguards, political or institutional pressure.

Far from being prescriptive, these questions are offered as summary and suggestion.

\section{Conclusions}

This article has considered the existing literature prohibiting, conceptualising and differentiating various types of threatening acts, whether verbal, non-verbal, explicit or implicit. It has canvassed and drawn on different legal contexts to look at how threats might rise to the level of torture. Explicating and elaborating the jurisprudence, it has been argued that the detainee's perception of the likelihood of the announced harm is central to any judicial assessment, and could be checked against the practice and proximity of state authorities to harm. Given contextual and subjective complexities, rule formulation is patently fraught. Indeed, as there is "no one kind of interrogation" there can be "no singular set of rules" (David et al, 2017 , p. 10), and legal text remains "rather 
abstract and not easily translated into concrete procedural rules for the interrogator" (Dimitriu, 2013, p. 561). Conceptualisation, however, is a necessary first step.

\section{References}

African Commission on Human and Peoples' Rights. (2014). Monim Elgak, Osman Hummeida and Amir Suliman v. Sudan. Comm 379/09.

Argitut, AEN, Ekimen, GAC, Jaiki Haidi et al. (2014). Incommunicado detention and torture. Assessments using the Istanbul Protocol. Marra \& Irredentos Books.

Baldwin, S., Fehrenbacher, A., \& Eisenman, D. (2014). Psychological Coercion in Human Trafficking: An Application of Biderman's Framework. Qualitative Health Research, 1(11).

Başoğlu, M. (ed). (2017). Torture and Its definition in international law: an interdisciplinary approach. New York: Oxford University Press. doi. org/10.1093/med/9780199374625.001.0001

Başoğlu, M., Livanou, M., Crnobaric, C., Frančišković, T., Suljić, E., Djuric, D, \& Vranesić, M. (2005). Psychiatric and Cognitive Effects of War in Former Yugoslavia: Association of Lack of Redress for Trauma and Posttraumatic Stress Reactions. $\mathcal{F} A M A$ 294. 580-90. doi:10.1001/ jama.294.5.580.

Başoğlu, M. (2009). A multivariate contextual analysis of torture and cruel, inhuman, and degrading treatments: Implications for an evidencebased definition of torture. American fournal of Orthopsychiatry, 79(2), 135-145. https://doi. $\operatorname{org} / 10.1037 / \mathrm{a} 0015681$

Brown K. (2015). Vulnerability and Young People: Care and Social Control in Policy and Practice. Bristol: Policy Press.

Cakal, E. (2018). Debility, dependency and dread: On the conceptual and evidentiary dimensions of psychological torture. Torture fournal, 28(2), pp. 15-37. doi: 10.7146/torture.v28i2.106908.

Cakal, E. (2019). Befogging reason, undermining will: Understanding sleep Deprivation as torture and other ill-treatment in international law. Torture fournal. 29(2), pp. 11-22. doi.org/10.7146/ torture.v29i2.109620

CAT. (2003). Inquiry procedure: Mexico, CAT/C/75.

CAT. (2008a). Concluding Observations on Kazakhstan. CAT/C/KAZ/CO/2.

CAT. (2006). Concluding Observations on USA. $\mathrm{CAT} / \mathrm{C} / \mathrm{USA} / \mathrm{CO} / 2$.

CAT. (2008b). Ali v. Tunisia. CAT/C/41/D/291/2006.

CAT. (2015). Larez v. Venezuela. CAT/
$\mathrm{C} / 54 / \mathrm{D} / 456 / 2011$.

CAT. (2015). Martinez v. Mexico. CAT/

$\mathrm{C} / 55 / \mathrm{D} / 500 / 2012$.

CAT. (2017). S.S.B v. Denmark. CAT/ $\mathrm{C} / 60 / \mathrm{D} / 602 / 2014$.

CAT. (2017b). General Comment 4 (2017) on the implementation of article 3 of the Convention in the context of article 22. CAT/C/GC/4.

CPT. (2002). 12th General Report, CPT/Inf (2002) 15.

David, G.C., Warfield Rawls, A., Trainum, J. (2017). Playing the Interrogation Game: Rapport, Coercion and Confessions in Police Interrogations. Symbolic Interaction, Vol 41 (1), pp. 3-24

Davis, D., \& O'Donohue, W. T. (2004). The road to perdition: "Extreme influence" tactics in the interrogation room. In W. T. O'Donohue, E. Levensky (Eds.) Handbook of forensic psychology (pp. 897-996). NY, Elsevier Academic Press.

Dehaghani, R. (2020). Interrogating Vulnerability: Reframing the Vulnerable Suspect in Police Custody. Social \& Legal Studies. https://doi. org/10.1177/0964663920921921

Dimitriu, G. (2013). Interrogation, Coercion and Torture: Dutch Debates and Experiences after 9/11, Intelligence and National Security. 28 (4), pp. 547-565.

ECCC. (2010). Duch, Case 001. Trial Chamber Judgment, 26 July 2010.

ECHR. (2009). Alexandru Marius Radu v. Romania. 34022/05, 21/07/2009.

ECHR. (1996). Aydin v. Turkey, 57/1996/676/866.

ECHR. (2018). Azzolina et Autres c. Italie, 28923/09 et $67599 / 10$.

ECHR. (2009). Bouyid v. Belgium. 23380/09 [GC].

ECHR. (1982). Campbell and Cosans v. United Kingdom. 7511/76, 7743/76.

ECHR. (2007). Dybeku v. Albania. 41153/06.

ECHR. (2012). El Masri v. Macedonia. 39630/09.

ECHR. (2004). Elci and Ors. v. Turkey. 23145/93 and 25091/94.

ECHR. (1980). Guzzardi v. Italy. 7367/76.

ECHR. (2010). Gäfgen v. Germany. 22978/05.

ECHR. (2014). Husayn (Zubaydah) v. Poland. $7511 / 13$.

ECHR. (2000). Fager v. the Netherlands (dec.), $39195 / 98$.

ECHR. (2000). Magee v. the UK, 28135/95.

ECHR. (2007). Musayev and Others v. Russia. 57941/00, 58699/00, 60403/00.

ECHR. (2011). Nechiporuk and Yonkalo v. Ukraine. $42310 / 04$

ECHR. (2016). Ortsuyeva and Others v. Russia. 
3340/08, 24689/10.

ECHR. (1999). Selmouni v. France. 25803/94.

ECHR. (1989). Soering v. United Kingdom. 14038/88.

ECommHR. (1969). Greek Case. Comm Rep, 5 Nov. 1969, 12 ECHRYb.

Ginbar, Y. (2008). Why not torture terrorists? Moral, practical, and legal aspects of the 'ticking bomb' justification for torture. Oxford University Press.

Gudjonsson, G. (2003). The Psychology of Interrogations and Confessions: A Handbook. (Wiley).

Guiora, A. N. (2008a). Interrogation of Detainees: Extending a Hand or a Boot? University of Michigan fournal of Law Reform, 41(2), 375.

Guiora, A. N. Coercive Interrogation, Threats, and Cumulative Mistreatment. 83-104. In Guiora, A. N. (2008b). Constitutional Limits on Coercive Interrogation. Oxford University Press. doi:10.1093/acprof: oso/9780195340310.003.0006

Hilgendorf E.L., Irving B. (1981). A DecisionMaking Model of Confessions. In: Lloyd-Bostock S.M.A. (eds) Psychology in Legal Contexts. Oxford Socio-Legal Studies. Palgrave Macmillan, London. doi.org/10.1007/978-1-349-04917-2_5

House of Commons Debates Hansard 8 September 2011, col. 572. as cited in Bates, E. 2019. Distorted Terminology: The UK's Closure of Investigations into Alleged Torture and Inhuman Treatment in Iraq. International and Comparative Law Quarterly, 1-21, p. 4. doi: $10.1017 /$ S002058931900023X

Human Rights Committee. (1990). Estrellav. Uruguay. 74/1980, CCPR/C/OP/2 at 93.

Human Rights Committee. (1994). Mukong v. Cameroon. 458/1991, CCPR-C-51-D-458-1991.

Human Rights Committee. (2007). Njaru v. Cameroon. 1353/2005.

Human Rights Committee. (2005) Khalilova v. Tajikistan, CCPR/C/83/D/973/2001.

Human Rights Committee. (2006). Bousroual v. Algeria, CCPR/C/86/D/1085/2002.

IACtHR. (2009) González v. Mexico, Preliminary Objection, Merits, Reparations, and Costs, Judgment, Series C No. 205.

IACtHR. (2006). Baldeón-García v. Peru. 06 April 2006. Series C No. 147.

IACtHR. (2000). Case of Cantoral-Benavides. Judgment of August 18, 2000. Series C No. 69.

IACtHR. (1999). Case of the "Street Children" (Villagran-Morales et al.) v. Guatemala.

IACtHR. (2007). Case of the Rochela Massacre v. Colombia. Merits, Reparations and Costs. Judgment of May 11, 2007. Series C No. 163

IACtHR. (2006). Goiburu et al v. Paraguay, Judgment,
22 September 2006, (Ser. C) No. 221.

IACtHR. (2003). Maritza Urrutia v. Guatemala. 27 November 2003. Series C No. 103.

IACtHR. (2004). Tibi v. Ecuador. Preliminary objections, merits, reparations and costs, IACHR Series C no 114, IHRL 1497, 7th September 2004.

International Committee of the Red Cross (ICRC). (1987). ICRC Commentary on the Additional Protocols of 8 fune 1977 to the Geneva Conventions of 12 August 1949. (Yves Sandoz, Christophe Swinarski \& Bruno Zimmermann eds. 1987)

International Committee of the Red Cross (ICRC). (1977). Protocol Additional to the Geneva Conventions of 12 August 1949, and relating to the Protection of Victims of International Armed Conflicts (Protocol I), 8 June 1977, 1125 UNTS 3.

International Committee of the Red Cross (ICRC). (1949). Geneva Convention Relative to the Treatment of Prisoners of War (Third Geneva Convention). 12 August 1949, 75 UNTS 135.

International Criminal Tribunal for the Former Yugoslavia (ICTY). (2001). Prosecutor v. Kunarac. IT-96-23-T \& IT-96-23/1-T, Judgment.

ICTY. (2002). Prosecutor v. Krnojelac. IT-97-25, Judgment.

ICTY. (2004). Prosecutor v. Brdanin, IT-99-36-T, Judgment, (Sept. 1, 2004).

ICTY. (2003). Prosecutor v. Simić, IT-95-9-T, Judgment, (Oct. 17, 2003).

ICTY. (1998). Prosecutor v. Delalić, IT-96-21-T, Judgment (Nov. 16, 1998)).

ICTY. (2000). Prosecutor v. Blaskic, IT-95-14-T, Judgment (Mar. 3, 2000).

ICTY. (2003). Prosecutor v. Naletilic, IT-98-34-T, Judgment (Mar. 31, 2003).

Inbau, F.E., Reid, J.E., Buckley, J.P., \& Jayne, B. C. (2003). Criminal Interrogation and Confessions. Jones \& Bartlett Learning.

Mendez, J. \& A. Nicolescu. (2017). Evolving Standards for Torture in International Law. In M. Basoglu. (2017). Torture and Its Definition in International Law. Oxford,

Nowak, M. \& McArthur E. (2008). United Nations Convention Against Torture: A Commentary. New York: Oxford University Press. https://doi. org/10.1093/law/9780199280001.001.0001

Ojeda, A. (ed). (2008). The Trauma of Psychological Torture. Praeger.

Olsen, D. R., Montgomery, E., Carlsson, J., Foldspang, A., \& Bøjholm, S. (2006). Prevalent pain and pain level among torture survivors. A follow up study. Disability and Rehabilitation, 29 (May), 210-214.

Oxford University Press (1990). The Concise Oxford 
Dictionary of Current English.

Public Committee Against Torture in Israel (PCATI). (2019). Torture in Israel 2019: Situation Report.

Pérez-Sales, P. (2017). Psychological Torture: Definition, Evaluation and Measurement. London: Routledge. https://doi.org/10.4324/9781315616940

Pérez-Sales, P. (2017b). Drawing the fine line between interrogation and torture: towards a Universal Protocol on Investigative Interviewing. Torture fournal. 27 (2).

Punamäki, R.-L., Qouta, S. R., \& Sarraj, E. El. (2010). Nature of torture, PTSD, and somatic symptoms among political ex-prisoners. Journal of Traumatic Stress, 23(4), 532-536.

Reyes, H. (2007). The worst scars are in the mind: psychological torture. International Review of the Red Cross, 89(867), 591-617. doi. org/10.1017/ s1816383107001300

Shaked-Schroer, N., Costanzo, M., Berger, D.E., (2015). Overlooking coerciveness - The impact of interrogation techniques and guilt corroboration on jurors' judgments of coerciveness. Legal and Criminological Psychology 20, pp. 68-80.

Türkiye İnsan Hakları Vakfı (Human Rights Foundation of Turkey). (2019). Tedavi ve Rehabilitasyon Merkezleri Raporu 2018 [Treatment and Rehabilitation Centres Report 2018].

UN General Assembly (UNGA). (1988). Body of Principles for the Protection of All Persons under Any Form of Detention or Imprisonment. A/RES/43/173.

UN General Assembly (UNGA). (1998). Rome Statute of the International Criminal Court (last amended 2010), 17 July 1998.

UN Office of the High Commissioner for Human Rights (OHCHR). (1999/2004). Manual on the Effective Investigation and Documentation of Torture and Other Cruel, Inhuman or Degrading Treatment or Punishment ('Istanbul Protocol'). HR/P/PT/8/ Rev. 1

United States Supreme Court. (2000). Dickerson v. United States. 530 US 428.

United States Supreme Court of Oregon. (1977). Oregon v. Mathiason. 424 US 492.

UNSRT. (1986). Report. E/CN.4/1986/15.

UNSRT. (1998). Report. E/CN.4/1998/38.

UNSRT. (2001). Report. A/56/156.

UNSRT. (2012). Report. A/67/279.

UNSRT. (2016). Report. A/71/298.

UNSRT. (2020). Report. A/HRC/40/59. 